Çukurova Üniversitesi Mühendislik Mimarlık Fakültesi Dergisi, 32(1), ss. 63-72, Mart 2017

Çukurova University Journal of the Faculty of Engineering and Architecture, 32(1), pp. 63-72, March 2017

\title{
Zonguldak Bölgesindeki Kayaçların Kıyı Koruma Yapılarında Kullanılabilirliğinin Araştırılması
}

\author{
Ali Can ÖZDEMÍR*1 \\ ${ }^{1}$ Çukurova Üniversitesi, Mühendislik Mimarlık Fakültesi, Maden Mühendisliği Bölümü, Adana
}

Geliş tarihi: 05.01.2017 Kabul tarihi: 14.03.2017

$\ddot{\mathbf{O z}}$

Kıyı şeridinin faydalı şekilde kullanılması ve korunması ülke ekonomisi açısından oldukça önemli bir yer tutmaktadır. Bu amaç doğrultusunda kıyı koruma yapılarının planlanması ve projelendirmesi aşamaları oldukça dikkatli uygulanmalıdır. Kıyı koruma yapıları için en önemli parametrelerden biri kullanılacak olan dolgu malzemesinin (kayaç) karakteristik özellikleridir. Bu çalışmanın amacı, Zonguldak bölgesinde bulunan taş ocaklarından elde edilen kayaç numunelerin kıy dolgusu ve sanat yapılarında kullanılabilirliğinin araştırılmasıdır. Bütün testler TS EN ve BS EN standartlarına göre uygulanmış ve sonuçlar değerlendirilmiştir. Elde edilen sonuçlar SK-2, ÇS-3, YL-4, KYP-5, AY-6 ve ARS-7 taş ocaklarının teknik şartname özelliklerini sağladığını göstermiştir. Ancak, EMM-1 taş ocağının heterojen yapısından dolayı selektif üretim uygulanırsa kullanılabilirliği belirlenmiştir.

Anahtar Kelimeler: Kıyı koruma yapıları, Zonguldak, Kayaç

\section{Investigation of Usability of Rocks in Zonguldak Area for Coastal Defence Structures}

\begin{abstract}
The use and protection of the coastline in beneficial way are very important in terms of the country's economy. For this purpose, the planning and projecting stages of the coastal defence structures should be applied carefully. One of the most important parameters for the coastal defence structures is characteristic features of the filler material (rock) that is being used. The aim of this study, to investigate the usability of the rock samples obtained from quarries in the Zonguldak area for coast filler and art structures. All tests were conducted according to TS EN and BS EN standards and the results were evaluated. The obtained results showed that the SK-2, ÇS-3, YL-4, KYP-5, AY-6 and ARS-7 quarries provide the technical specification properties. However, it was determined that EMM-1 quarry can be used when the selective production was performed due to its heterogeneous structure.
\end{abstract}

Keywords: Coastal defence structures, Zonguldak, Rock

\footnotetext{
"Sorumlu yazar (Corresponding author): Ali Can ÖZDEMIR, acozdemir@cu.edu.tr
} 


\section{GíRiş}

Üç tarafı denizlerle çevrili olan ülkemizde, kıyıların en iyi şekilde kullanımının hem deniz ulaşımı hem de turizm açısından ülke ekonomisinin büyümesinde oldukça büyük payı olmaktadır. Deniz ulaşımının en ekonomik ulaşım sektörü olması ve ülkemizin transit deniz ulaşım yolları üzerinde bulunması bu payı daha da artırmaktadır. Bu nedenle kıyıların en iyi şekilde korunması ve geliştirilmesi gerekmektedir [1].

Deniz yapılarında kullanılacak kaya malzemelerinin seçilmesinde dikkat edilmesi gereken başlıca temel özellikler; renk, yoğunluk, su emme, porozite, süreksizliklerin konumu, ayrışma durumu, mukavemeti, sertliği, tane boyu dağılımı, blok bütünlüğü, blok şekli, blok ağırlığı ve boyutu olarak sıralanabilir. Deniz yapılarında kullanılacak doğal yapı malzemelerinin belirlenmesinde ilk adım olarak jeolojik inceleme yapılmalı ve potansiyel kaya malzemesi öncelikle kaynağında incelenmelidir. Uygun kaya malzemesi taş ocağında yapılacak kayanın fiziksel ve jeolojik özelliklerinin ayrıntılı değerlendirilmesine dayalı olarak seçilmelidir. Belirli bir kaynak tespit edildiğinde dikkatlice araştırılmalıdır. Ayrışmayla birlikte kayaçların mineralojisi, oluşumu, süreksizliklerin durumu, bölgesel metamorfizma, tektonizma ve faylanma kaya kalitesini belirleyen önemli faktörlerdir [2].

$\mathrm{Bu}$ çalışma, Zonguldak İli, Karadeniz Ereğli ve Merkez İlçesi sınırlarında bulunan kayaç numunelerinin kıy koruma yapılarında kullanılabilirliğinin araştırılmasını kapsamaktadır. $\mathrm{Bu}$ kapsamda çalışma alanını temsil etmesi açısından 7 farklı bölgeden kayaç örnekleri alınmıştır. Daha sonra laboratuvar ortamında ilgili standartlara uygun olarak deneyler gerçekleştirilmiş ve sonuçlar değerlendirilmiştir.

\section{MATERYAL VE METOT}

\subsection{Materyal}

$\mathrm{Bu}$ çalışmada blok numuneler de dahil olmak üzere farklı boyut ve özellikte kayaç numuneleri kullanılmıştır. Materyal olarak araştırılan kayaç numuneleri Zonguldak İli, Karadeniz Ereğli ve Merkez İlçesi sınırlarında 7 farklı bölgede bulunan taş ocaklarından (EMM-1, SK-2, ÇS-3, YL-4, KYP-5, AY-6 ve ARS-7/Ocakların isimleri gizlenmiştir) elde edilmiştir.

\subsection{1. Çalışma Alanının Konumu}

Çalışma alanı Zonguldak İli, Karadeniz Ereğli ve Merkez ilçesi olarak sınırlandırılmıştır. Şekil 1'de çalışma alanının yer bulduru haritası görülmektedir.

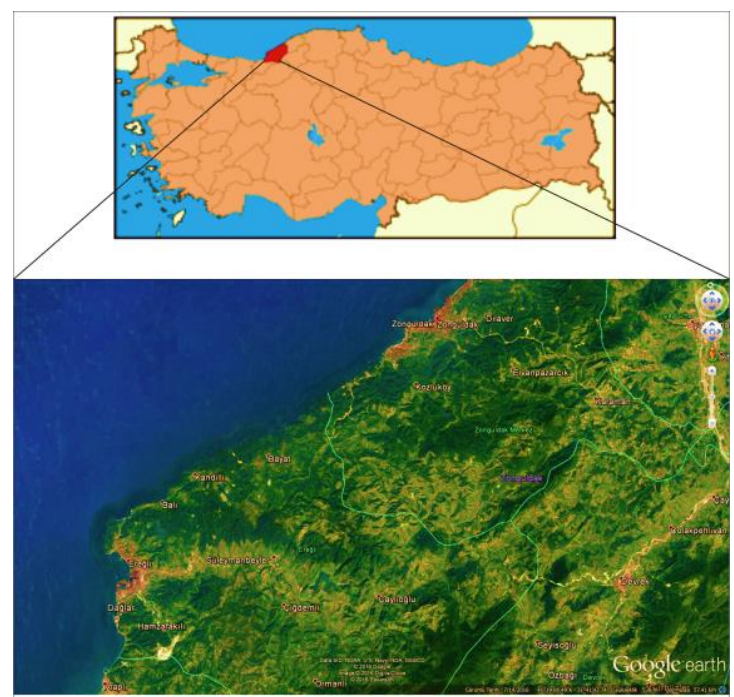

Şekil 1. Çalışma alanı yer bulduru haritası

\subsection{Metot}

Çalışma alanından alınan deney numunelerinin kıyı koruma yapılarında kullanılabilirliği TS EN 13383-1 [8], TS EN 13383-2 [9], TS 706 EN $12620+\mathrm{A} 1$ [10], TS EN 1467 [11] standartları ve CIRIA/CUR [12] kıyı mühendisliği el kitabı temel alınarak araştırılmıştır.

\subsubsection{Kimyasal Analiz}

Deney numunelerinin kimyasal içeriklerini ve bünyesinde bulunan elementlerin miktarını belirlemek amac1 ile kimyasal analiz yapılmaktadır. $\mathrm{Bu}$ çalışmada kimyasal analiz yöntemlerinden $\mathrm{X}$-1şını floresans (XRF) yöntemi 
uygulanmıstır. Kimyasal analizde kullanılacak olan deney numuneleri, ocağı temsil etmesi açısından tüm kayaç numunelerinden alınan parçaların öğütülmesi ve konileme-dörtleme yöntemi ile azaltılması işlemlerinden elde edilmiştir. Elde edilen bu deney numunelerinin kimyasal içerikleri XRF deney cihazı yardımı ile belirlenmiştir.

\subsection{2. Özgül Ağırlık (Tane Yoğunluğu)}

Bir kayacın bağıl (boşlukları ihmal edilmiş) yoğunluğu özgül ağırlık olarak adlandırılır. Özgül ağırlık hesaplamalarında yaygın olarak piknometre yöntemi kullanılmaktadır. Bu yöntemde, deney numunesi 0,2 mm'lik elekten geçecek şekilde öğütülür. Öncelikle boş piknometre ağırlığı tartılır daha sonra piknometrenin 4/3'lük kısmı deney numunesi ile doldurulur ve bu şekilde tartım yapılır. Sonrasında numune ile dolu olan piknometrenin içerisinde saf su doldurulur ve tekrar tartım alınır. Son olarak piknometre boşaltılıp temizlenir ve sadece saf su ile doldurulur ve tartım alınır. $\mathrm{Bu}$ işlemlerden sonra aşağıdaki formül ile özgül ağırlık değeri hesaplanır [13].

$$
G_{S}=\frac{\left(W_{2}-W_{1}\right)}{\left(W_{4}-W_{1}\right)-\left(W_{3}-W_{2}\right)}
$$

$\mathrm{W}_{1}=$ Boş piknometre ağırlı̆̆

$\mathrm{W}_{2}=$ Piknometre + numune ağırlığı $(\mathrm{g})$

$\mathrm{W}_{3}=$ Piknometre+ numune + su ağırlığ $(\mathrm{g})$

$\mathrm{W}_{4}=$ Piknometre + su ağırlı̆ $1(\mathrm{~g})$

$\mathrm{G}_{\mathrm{S}}=$ Özgül Ağırlık

\subsubsection{Ağırlıkça Su Emme Oranı}

Bir kayacın ağırlık bazında bünyesinde ne kadar miktarda su bulunduğunu ölçmek amacıyla ağırlıkça su emme deneyi uygulanır. Deney numuneleri sabit tartıma gelinceye kadar etüvde kurutulur. Sabit tartıma gelen deney numunesinin hassas terazide tartımı yapılır. Daha sonra desikatörde bekletilen deney numunesi tüm yüzeyleri su ile temas edilecek şekilde su dolu kabın içerisine bırakılır. Yaklaşık 48 saat süre geçtikten sonra su içerisinden çıkarılır ve hafifçe yüzey üzerindeki ıslaklık alındıktan sonra aynı hassas terazi ile tartımı yapılır. Elde edilen tartım verileri aşağıdaki formülde yerine koyularak ağırlıkça su emme değeri hesaplanır [13].

$A_{w}=\frac{W_{d}-W_{k}}{W_{k}} \times 100$

$\mathrm{W}_{\mathrm{d}}=$ Numunenin doygun ağırlığg $1(\mathrm{~g})$

$\mathrm{W}_{\mathrm{k}}=$ Numunenin kuru ağırlı̆̆ $(\mathrm{g})$

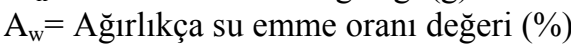

\subsubsection{Birim Hacim Ağırlık}

$\mathrm{Bu}$ deney ile kayaç numunesinin kütlesel (gözenekler dahil) birim hacim ağırlık değeri hesaplanmaktadır. Deney numunesinin hacim ve ağırlık değerleri ölçülür. Daha sonra aşağıdaki formül ile birim hacim ağırlık değeri hesaplanır [14].

$\rho=\frac{\mathrm{W}}{\mathrm{V}}$

$\mathrm{W}=$ Numune ağırlığ

$\mathrm{V}=$ Numune hacmi $\left(\mathrm{cm}^{3}\right)$

$\rho=$ Birim hacim ağırlık $\left(\mathrm{g} / \mathrm{cm}^{3}\right)$

\subsubsection{Los Angeles Aşınma Kaybı}

Bir kayaç numunesinin aşınmaya karşı gösterdiği dayanım mekanik özellikler arasında oldukça önemli yer tutmaktadır. Bu dayanımı belirlemek için farklı deney yöntemleri vardır. Ancak en yaygın olarak kullanılan yöntem Los Angeles aşınma kaybı deneyidir. $\mathrm{Bu}$ deney için $-16+14 \mathrm{~mm}$ boyutunda $2500 \mathrm{~g} ;-14+12,5 \mathrm{~mm}$ boyutunda $2500 \mathrm{~g}$ olmak üzere toplam $5000 \mathrm{~g}$ agrega numunesi hazırlanır. Los Angeles deney tamburu içerisine atılan deney numuneleri üzerine çelik bilyalar bırakılır ve tamburun ağzı kapatıldıktan sonra 31 devir/dakika sabit hızla 500 devir dönüşü tamamlaması beklenir. Tamburun dönüşü tamamlandıktan sonra deney numunesi tamburdan çıkarılır ve bilyeler ayıklandıktan sonra 1,6 $\mathrm{mm}$ açıklıktaki elekten eleme yapılır ve elek üstü malzemenin tartımı alınır. Los Angeles aşınma kaybı miktarı aşağıdaki formül ile hesaplanır [15]. 


$$
L A=\frac{5000-m}{50}
$$

$\mathrm{m}=1,6 \mathrm{~mm}$ 'lik elek üstü malzeme miktarı $(\mathrm{g})$ LA= Los Angeles aşınma kaybı değeri

\subsubsection{Don Kaybı (MgSO 4 Yöntemi)}

Deney sirasinda tartım yapilarak en az 500 gr ağırlığında ve 10-14 mm boyut aralığında agrega numunesi magnezyum sülfat çözeltisine daldırılır ve 17 saat beklenir. Daha sonra deney numunesinin 2 saat süzülmesi beklenir ve sonrasında 5 saat süre ile etüvde kurutulur. $\mathrm{Bu}$ işlemler periyodik olarak 5 sefer tekrarlanır. Döngü tamamlanıp deney numunesi $10 \mathrm{~mm}$ 'lik elekten geçirildikten sonra elek üzerinde kalan malzeme tekrar tartılır. Magnezyum sülfatın tekrar su alması ve agrega numunesinde tekrarlanan kristalizasyon ile agrega boşluklarında zararlı etkiler ortaya çıkar. Tane büyüklüğü $10 \mathrm{~mm}$ 'den daha küçük malzemelerin oluşmasına neden olan zararlı etkilerin neden olduğu ufalanma ölçülür. Tartım işleminden sonra aşağıdaki eşitlik ile Don kaybı kütlece yüzde olarak hesaplanır [16].

$$
M_{S}=\frac{M_{1}-M_{2}}{M_{1}} \times 100
$$

$\mathrm{M}_{1}=$ Deney numunesinin ilk kütlesi $(\mathrm{g})$

$\mathrm{M}_{2}=$ Deney numunesinin son kütlesi $(\mathrm{g})$

$\mathrm{M}_{\mathrm{s}}=$ Donma-Çözünme kaybı (\%)

\subsubsection{Tek Eksenli Basınç Dayanımı}

$\mathrm{Bu}$ deney ile numunenin düşey yönde uygulanan kuvvet karşısında kırılmaya karşı gösterdiği direnç hesaplanmaktadır. Deney numunesi küp veya silindir (boy/çap oranı= 2-2,5) olacak şekilde hazırlanmalıdır. Hazırlanan deney numunesinin yüzey alanı ölçüldükten sonra hidrolik pres makinesi yardımıyla düşey yönde kuvvet uygulanır ve numunenin kırılma yükü kayıt altına alınır. Deney numunesinin kırılma yükünün yüzey alanına oranı tek eksenli basınç dayanımı değerini verir [17].
$\sigma_{b}=\frac{F}{A}$

$\mathrm{F}=$ Numunenin kırılma yükü (kgf)

$\mathrm{A}=$ Numunenin yüzey alanı $\left(\mathrm{cm}^{2}\right)$

$\sigma_{\mathrm{b}}=$ Tek eksenli basınç dayanımı $\left(\mathrm{kgf} / \mathrm{cm}^{2}\right)$

\subsubsection{Sürtünme ile Aşınma Kaybı (Böhme Metodu)}

$\mathrm{Bu}$ deneyde 30 devir/dk. \pm 1 devir/dk hızla dönmesini sağlayan yaklaşık $750 \mathrm{~mm}$ çapında yatay olarak yerleştirilmiş döner bir aşındırma diski bulunmaktadır. Numuneye dönen disk üzerinde belirli bir kuvvet uygulayan donanım yüzey aşındırıcı olarak kullanılmaktadır. Sürtünme ile aşınma kaybı deneyi için kenar uzunlukları $71 \mathrm{~mm} \pm 1,5 \mathrm{~mm}$ olan küp numuneler hazırlanmıştır. Deneyde yaklaşık 20 g zımpara tozu (korundum) sürtünme şeridi üzerine serpilir ve çelik manivela aracılığı ile $294 \pm 3 \quad \mathrm{~N}$ ile yüklenir. 22 devir sonunda otomatik olarak duran disk üzerinden zımpara tozu ve numune atıkları temizlenir. Numune düşey eksen etrafinda $90^{\circ}$ çevrilir. Her numune için 22 devir'den oluşan deney 16 defa tekrarlanır. Deney numunesi iyice temizlendikten sonra numune hassas terazide tartılır. Aşağıdaki Eşitlik (7) kullanılarak toplam hacim kaybı hesaplanır [18].

$\Delta V=\frac{\Delta m}{\rho}$

$\Delta \mathrm{V}=$ Toplam hacim kayb1 $\left(\mathrm{cm}^{3} / 50 \mathrm{~cm}^{2}\right)$

$\Delta \mathrm{m}=$ Toplam ağırlık kaybı $\left(\mathrm{g} / 50 \mathrm{~cm}^{2}\right)$

$\rho=$ Numune yoğunluğu $\left(\mathrm{g} / \mathrm{cm}^{3}\right)$

\subsubsection{Arazide Düşürme Testi}

$\mathrm{Bu}$ deney, blok numunelere yüksekten düşmeye karşı direncini ölçmek amacı ile uygulanmaktadır. Zeminde duran bir blok numunenin üzerine aynı özellikleri taşıyan başka bir blok numune yaklaşık $3 \mathrm{~m}$ yükseklikten bırakılır. Daha sonra her iki bloğun fiziksel yapılarını koruyup korumadığına bakılır ve blok numunelerde oluşan deformasyon miktarı ölçülür [19]. 


\subsubsection{Ayrışma Derecesi Tayini}

Arazide düşme testine tabi tutulan örneklerden çıplak göz, lup ve binoküler mikroskop altında incelemeye uygun el örnekleri hazırlanmış ayrıcı benzer numunelerden değişik doğrultularda 5'er adet ince kesit hazırlanarak incelenmiştir [12, 20].

\subsubsection{Petrografik Tanımlama}

$\mathrm{Bu}$ deneyde taş ocaklarını temsil edecek şekilde alınan el örneklerinden ince kesitler hazırlanmış olup polarizan mikroskop ile incelenerek kayaç tanımlamaları yapılmıştır [21, 22].

\section{ARASTIRMA BULGULARI}

Zonguldak Karadeniz Ereğlisi sınırlarında bulunan farklı bölgelerden alınmış olan deney numuneleri üzerinde ayrıntıları önceki bölümde verilmiş olan deneyler uygulanmış olup elde edilen sonuçlar aşağıda verilmiştir.

\subsection{Kimyasal Analiz}

Deney numuneleri üzerinde kimyasal analiz deneyi uygulanmış ve analiz sonuçları Çizelge 1'de verilmiştir.

Çizelge 1. Deney numunelerinin kimyasal analiz sonuçları

\begin{tabular}{|c|c|c|c|c|c|}
\hline Numune Ad & $\mathbf{C a O}-\mathbf{C a C O}_{\mathbf{3}}$ & $\mathbf{M g O}-\mathbf{M g C O}_{\mathbf{3}}$ & $\mathbf{S i O}_{\mathbf{2}}$ & $\mathbf{A l}_{\mathbf{2}} \mathbf{O}_{\mathbf{3}}$ & $\mathbf{F e}_{\mathbf{2}} \mathbf{O}_{\mathbf{3}}$ \\
\hline EMM-1 & $33,97-60,66$ & $1,19-2,50$ & 24,00 & 5,37 & 3,17 \\
\hline SK-2 & $43,42-77,53$ & $0,19-0,41$ & 8,65 & 2,60 & 5,05 \\
\hline ÇS-3 & $53,86-96,18$ & - & 1,71 & 0,65 & 0,69 \\
\hline YL-4 & $45,77-81,74$ & $7,19-15,10$ & 1,70 & - & 0,70 \\
\hline KYY-5 & $53,98-96,40$ & $0,20-0,42$ & 1,60 & 0,32 & 0,30 \\
\hline AY-6 & $55,38-98,90$ & $0,14-0,30$ & - & 0,36 & 0,22 \\
\hline ARS-7 & $55,22-98,61$ & $0,17-0,35$ & - & 0,22 & 0,15 \\
\hline
\end{tabular}

\section{2. Özgül Ağırlık (Tane Yoğunluğu)}

Deney numuneleri üzerinde özgül ağırlık (piknometre metodu) deneyi uygulanmış ve numunelere ait ortalama deney sonuçları Çizelge 2'de verilmiştir.

Çizelge 2. Ortalama özgül ağırlık değerleri

\begin{tabular}{|c|c|}
\hline Numune Adı & Özgül Ağırlık $\left(\mathrm{g} / \mathrm{cm}^{3}\right)$ \\
\hline EMM-1 & 2,720 \\
\hline SK-2 & 2,719 \\
\hline ÇS-3 & 2,682 \\
\hline YL-4 & 2,802 \\
\hline KYP-5 & 2,710 \\
\hline AY-6 & 2,700 \\
\hline ARS-7 & 2,695 \\
\hline
\end{tabular}

\subsection{Ağırlıkça Su Emme Oranı}

Deney numuneleri üzerinde ağırlıkça su emme oranı deneyi uygulanmış ve numunelere ait ortalama deney sonuçları Çizelge 3 'de verilmiştir.

Çizelge 3. Ortalama ağırlıkça su emme değerleri

\begin{tabular}{|c|c|}
\hline Numune Adı & $\begin{array}{c}\text { Ağırlıç̧a Su Emme } \\
\text { Oranı }(\%)\end{array}$ \\
\hline EMM-1 & 0,209 \\
\hline SK-2 & 0,157 \\
\hline ÇS-3 & 0,540 \\
\hline YL-4 & 0,172 \\
\hline KYP-5 & 1,224 \\
\hline AY-6 & 0,448 \\
\hline ARS-7 & 0,148 \\
\hline
\end{tabular}




\subsection{Birim Hacim Ağırlık}

Deney numuneleri üzerinde birim hacim ağıllık deneyi uygulanmış ve numunelere ait ortalama deney sonuçları Çizelge 4'de verilmiş̧ir.

Çizelge 4. Ortalama birim hacim ağırlık değerleri

\begin{tabular}{|c|c|}
\hline Numune Adı & $\begin{array}{c}\text { Birim Hacim Ağıllık } \\
\left(\mathrm{g} / \mathrm{cm}^{3}\right)\end{array}$ \\
\hline EMM-1 & 2,509 \\
\hline SK-2 & 2,527 \\
\hline ÇS-3 & 2,571 \\
\hline YL-4 & 2,717 \\
\hline KYP-5 & 2,499 \\
\hline AY-6 & 2,510 \\
\hline ARS-7 & 2,543 \\
\hline
\end{tabular}

\subsection{Los Angeles (LA) Aşınma Kaybı}

Deney numuneleri üzerinde Los Angeles aşınma kaybı deneyi uygulanmış ve numunelere ait deney sonuçları Çizelge 5'de verilmiştir.

Çizelge 5. Ortalama LA Aş̧nma kaybı değerleri

\begin{tabular}{|c|c|c|}
\hline Numune Adı & Elek Üstü (g) & LA (\%) \\
\hline EMM-1 & 3898 & 22,04 \\
\hline SK-2 & 4020 & 19,60 \\
\hline ÇS-3 & 4046 & 19,80 \\
\hline YL-4 & 4106 & 17,58 \\
\hline KYP-5 & 4116 & 17,68 \\
\hline AY-6 & 4120 & 17,60 \\
\hline ARS-7 & 4100 & 18,00 \\
\hline
\end{tabular}

\subsection{Don Kaybı ( $\mathrm{MgSO}_{4}$ Yöntemi)}

Deney numuneleri üzerinde Don kaybı $\left(\mathrm{MgSO}_{4}\right)$ deneyi uygulanmış ve numunelere ait deney sonuçları Çizelge 6'da verilmiştir.
Çizelge 6. Ortalama Don kaybı değerleri

\begin{tabular}{|c|c|c|}
\hline Numune Ad 1 & Kütle Kaybı (g) & Kategori \\
\hline EMM-1 & 8,39 & M18 \\
\hline SK-2 & 1,98 & M18 \\
\hline ÇS-3 & 1,49 & M18 \\
\hline YL-4 & 6,80 & M18 \\
\hline KYP-5 & 2,10 & M18 \\
\hline AY-6 & 2,06 & M18 \\
\hline ARS-7 & 3,04 & M18 \\
\hline
\end{tabular}

\subsection{Tek Eksenli Basınç (TEB) Dayanımı}

Deney numuneleri üzerinde tek eksenli basınç dayanımı deneyi uygulanmış ve numunelere ait ortalama deney sonuçları Çizelge 7'de verilmiştir.

Çizelge 7. Ortalama TEB dayanımı değerleri

\begin{tabular}{|c|c|c|}
\hline Numune Adı & $\begin{array}{c}\text { TEB } \\
\text { Dayanımı } \\
\left(\mathrm{kgf} / \mathrm{cm}^{2}\right)\end{array}$ & $\begin{array}{c}\text { TEB } \\
\text { Dayanımı } \\
(\mathrm{MPa})\end{array}$ \\
\hline EMM-1 & 892,60 & 87,50 \\
\hline SK-2 & 866,44 & 84,97 \\
\hline ÇS-3 & 873,60 & 85,67 \\
\hline YL-4 & 844,35 & 82,80 \\
\hline KYP-5 & 1087,21 & 106,62 \\
\hline AY-6 & 826,36 & 81,04 \\
\hline ARS-7 & 793,50 & 77,80 \\
\hline
\end{tabular}

\subsection{Sürtünme ile Aşınma Kaybı (Böhme Metodu)}

Deney numuneleri üzerinde sürtünme ile aşınma kaybı (böhme metodu) deneyi uygulanmış ve numunelere ait ortalama deney sonuçları Çizelge 8'de verilmiştir.

Çizelge 8. Ortalama Böhme aşınma kaybı değerleri

\begin{tabular}{|c|c|}
\hline Numune Adı & $\begin{array}{c}\text { Böhme Aşınma Kayb1 } \\
\left(\mathrm{cm}^{3} / 50 \mathrm{~cm}^{2}\right)\end{array}$ \\
\hline EMM-1 & 14,14 \\
\hline SK-2 & 13,44 \\
\hline CSS-3 & 13,10 \\
\hline YL-4 & 13,95 \\
\hline KYP-5 & 13,13 \\
\hline AY-6 & 13,15 \\
\hline ARS-7 & 13,86 \\
\hline
\end{tabular}




\subsection{Arazide Düşürme Testi}

Deney numuneleri üzerinde arazide düşürme testi uygulanmıştır. Deney sırasında elde edilen taş ocaklarının görüntüsü Şekil 2-8'de verilmiștir. Bu deney açısından bütün ocaklar gerekli kriterleri sağlamıştır.

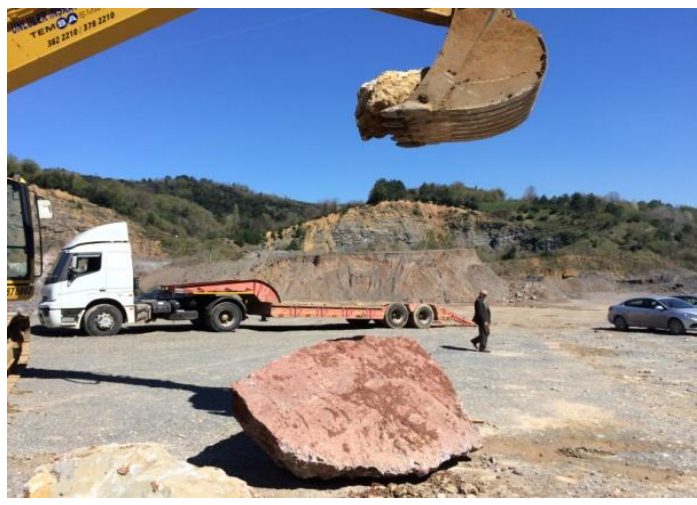

Şekil 2. EMM-1 taş ocağ1

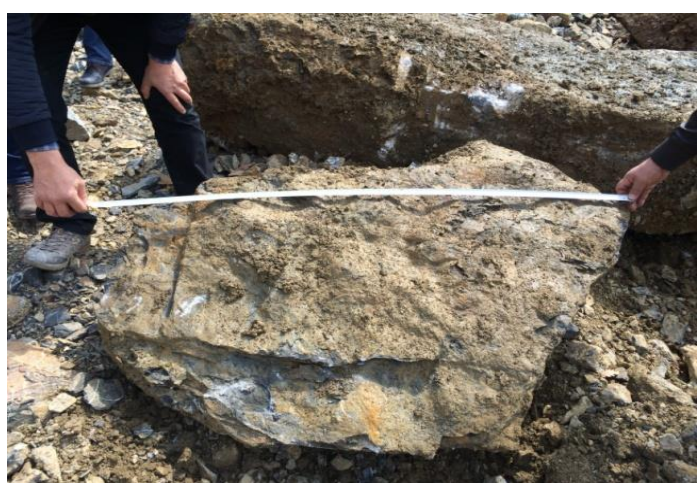

Şekil 3. SK-2 taş ocağı

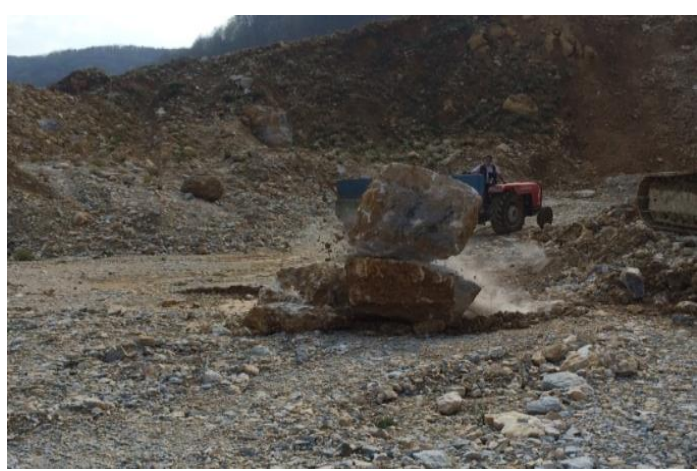

Şekil 4. ÇS-3 taş ocağı

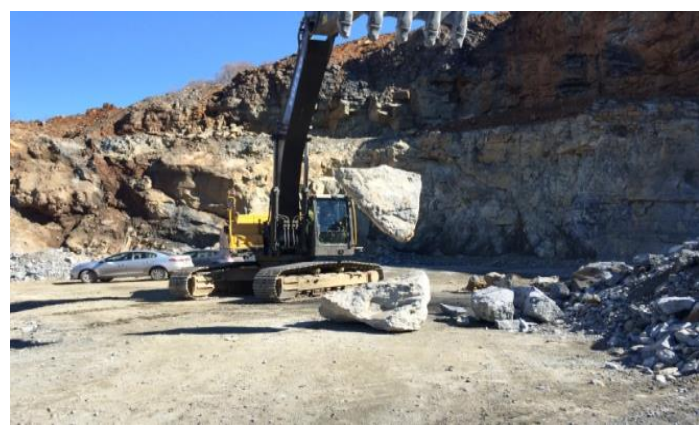

Şekil 5. YL-4 taş ocağ 1

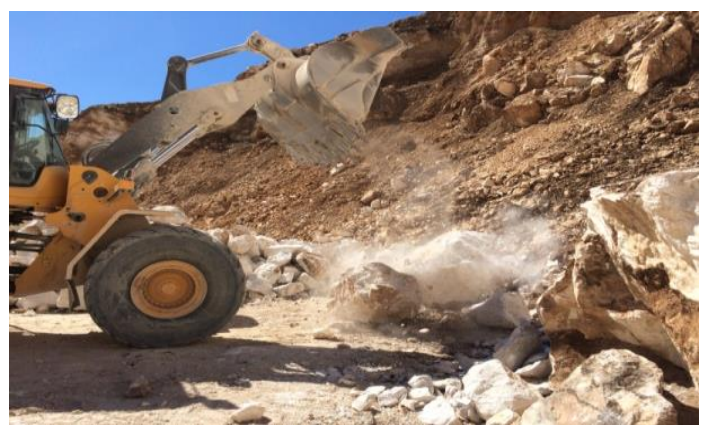

Şekil 6. KYP-5 taş ocağı

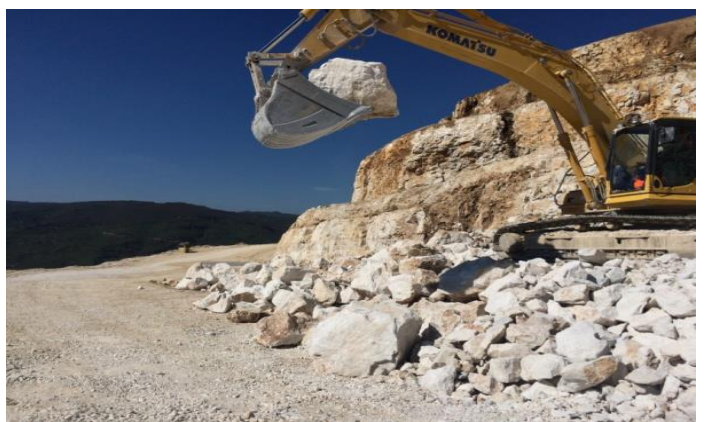

Şekil 7. AY-6 taş ocağ1

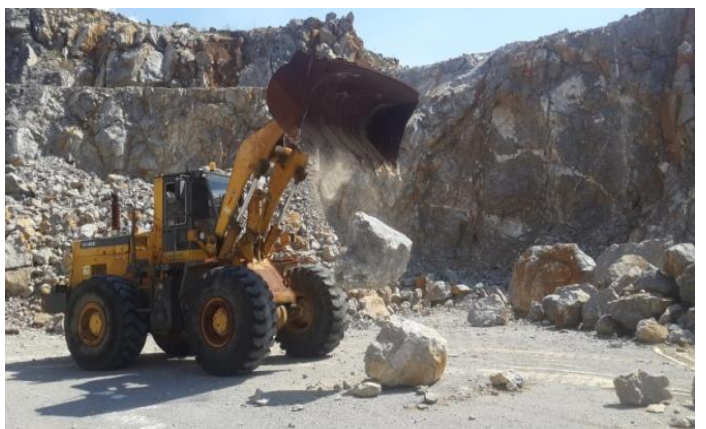

Şekil 8. ARS-7 taş ocağ1 


\subsection{Ayrışma Derecesi Tayini}

Deney numuneleri üzerinde ayrışma dereci tayini yapılmış olup elde edilen deney sonuçları Çizelge 9'da verilmiştir.

Çizelge 9. Ayrışma derecesi deney sonuçları

\begin{tabular}{|c|c|}
\hline Numune Ad1 & Ayrışma Derecesi \\
\hline EMM-1 & IB \\
\hline SK-2 & IB \\
\hline ÇS-3 & IB \\
\hline YL-4 & IA-IB \\
\hline KYP-5 & IB \\
\hline AY-6 & IB \\
\hline ARS-7 & IB \\
\hline
\end{tabular}

\subsection{Petrografik Analiz}

Deney numuneleri üzerinde yapılan petrografik analizler ışı̆̆ında kayaç adlandırmaları yapılmış olup elde edilen sonuçlar Çizelge 10'da verilmiştir.

Çizelge 10. Petrografik Analiz sonuçları

\begin{tabular}{|c|c|}
\hline Numune Ad1 & Deney Sonucu \\
\hline \multirow{2}{*}{ EMM-1 } & Kumtaş1 \\
\cline { 2 - 2 } & Konglomera \\
\hline SK-2 & Silisli Kalker \\
\hline ÇS-3 & Kalker \\
\hline YL-4 & Dolomitik Kalker \\
\hline KYP-5 & Saf Kalker \\
\hline AY-6 & Saf Kalker \\
\hline ARS-7 & Saf Kalker \\
\hline
\end{tabular}

\section{SONUÇLAR}

Bu çalışmada, fiziksel, mekanik, kimyasal ve petrografik özellikleri ayrı ayrı değerlendirilen EMM-1, SK-2, ÇS-3,YL-4, KYP-5, AY-6, ve ARS-7 taş ocaklarında blokların homojenlik ve sağlamlık bakımından birbirine oldukça benzer özellik taşıdıkları anlaşıımıștır. Ancak taş ocaklarında arazide düşürme testleri yapılırken genel görünüm ve blok verimi bakımından farkl11ıklar olduğu görülmüștür. EMM-1 taş ocağ kumtaşı ve çok orijinli konglomera olmak üzere iki farklı litolojiden oluşmuş olduğu görülmüştür. Diğer taş ocakları oldukça homojen karakterdedir. Arazide düşürme testinde EMM-1 ocağına ait kumtaşı bloğu konglomera üzerine düşürülmüştür. Oldukça dayanıklı olduğu anlaşılan blokların ayrı ayrı litolojide üretilmesi ve şiştik özellik gösteren çamurtaşı gibi suya dayanıksız kısımların ayıklanması halinde (selektif kazı) tercih edilerek kullanılabileceği anlaşılmıştır. KYP-5 ve AY-6 taş ocakları esas olarak masif kireçtaşlarından oluşan fiziksel ve mekanik özellikleri birbirine çok yakın olan saf kalker sinıfindadır. $\mathrm{Bu}$ ocaklardan türetilen blok ve el örneklerinin teknik şartnameye de en uygun özellikler gösteren taşocakları olduklar1 görülmektedir. Sonuçlar değerlendirilirken TS EN 13383-1 [8], TS EN 13383-2 [9], TS 706 EN $12620+$ A1 [10], TS EN 1467 [11], CIRIA/CUR [12] standartları ve Çizelge 11'de verilmiş olan karayolları teknik şartnamesi [19] dikkate alınmıştır.

Çizelge 11. Karayolları teknik şartnamesi

\begin{tabular}{|c|c|c|}
\hline Deney & Şartname Limitteri & Deney StandardI \\
\hline Ayrrșma derecesi & I-III & \\
\hline Süreksizlik arallğı̆ (m) & $1.00+$ & \\
\hline RQD (\%) & $80-100$ & \\
\hline Petrografik Görünüm & $\begin{array}{l}\text { Kristaller iyi kenetlenmiş, kil } \\
\text { minerali ve eriyebilir mineral } \\
\text { olmayacaktır. }\end{array}$ & ASTM C 295 \\
\hline $\begin{array}{l}\text { Doygun Yüzey Kuru Birim Hacım } \\
\text { Ağırll/k }\left(\mathrm{gr}^{\prime} / \mathrm{cm}^{3}\right)\end{array}$ & $\geq 2.50^{3}$ & \multirow{8}{*}{$\begin{array}{c}\text { TS 699-Ocak } \\
1987 \\
\text { TS 2513-Şubat } \\
1977 \\
\text { TS EN 13383-1 } \\
\text { ve TS EN 13383- } \\
\text { 2-Nisan 2004 }\end{array}$} \\
\hline Hacımca Su Emme Oranı \% & $\leq 3.0$ & \\
\hline Basınç Dayanımı $\left(\mathrm{kgf} / \mathrm{cm}^{2}\right)$ & $\geq 500$ & \\
\hline $\begin{array}{l}\text { Kaba Agregada Los Angeles } \\
\text { Așınma Direnci \% }\end{array}$ & $\leq 40$ & \\
\hline Tabii Don Dayanımı \% & $\leq 5$ & \\
\hline Don Kaybi Deneyi $\left(\mathrm{Mg}_{2} \mathrm{SO}_{4}\right) \%$ & $\leq 25$ & \\
\hline Don Kaybı Deneyi $\left(\mathrm{Na}_{2} \mathrm{SO}_{4}\right) \%$ & $\leq 18$ & \\
\hline Sürtünme ile Așınma Kaybı & $\leq 15 \mathrm{~cm}^{3} / 50 \mathrm{~cm}^{2}$ & \\
\hline Arazide Düşürme Testi & $\begin{array}{l}\text { Ana boyutta kirılma olmayacak } \\
\text { ve çatlak oluşmayacaktır. }\end{array}$ & \\
\hline $\begin{array}{l}\text { Arazide Bekleme - Yerinde } \\
\text { Gözlem }\end{array}$ & \multicolumn{2}{|c|}{$\begin{array}{l}\text { Ocak yerinde veya kullanılacağı yerde } 12 \text { ay } \\
\text { beklediği sürede çatlak oluşumu, parçalanma ve } \\
\text { ayrıșma olmayacaktır. }\end{array}$} \\
\hline \multicolumn{3}{|c|}{ 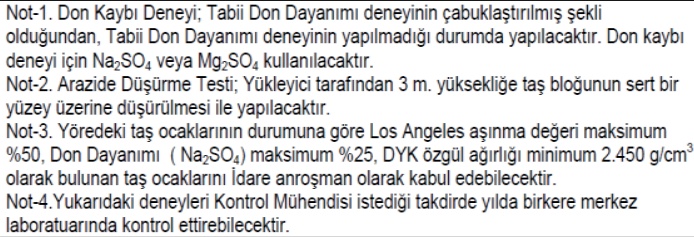 } \\
\hline
\end{tabular}

Çizelge 11 'de belirtilen sinır değerler esas alındığında; yapılan deneyler sonucunda her 7 ocağın da şartnameye uygun olduğu anlaşılmaktadır. 
Deney sonuçları ayrıntılı olarak değerlendirildiğinde ise tane yoğunluğu, ağırlıkça su emme, birim hacim ağırlıkları değerleri bakımından 7 ocak içinde büyük benzerlikler görülmektedir. Ancak parçalanmaya karşı direnç (Los Angeles) değeri en az olan (en sağlam) YL-4 taş ocağ ocaklarının onu takip ettikleri görülmektedir. Donma-çözünme sonrası kütle kaybı değerleri bakımından kütle kaybı (\%) değeri en az olan (en sağlam) ÇS-3 taş ocağ1 olup, SK-2 ve AY-6 onu takip etmektedir. Tek Eksenli Basınç Dayanımı değeri en yüksek olan (en sağlam) KYP-5 taş ocağ 1 olup, EMM-1, ÇS-3 ve SK-2 taş ocakları onu takip etmektedirler. Petrografik tanımlamada EMM-1 taş ocağından alınan örneklerin Kumtaşı ve Konglomera, SK-2 taş ocağından Silisli Kalker, ÇS-3 taş ocağından alınan örneklerin Kalker, YL-4 taş ocağından alınan örneklerin Dolomitik Kalker, KYP-5, AY-6 ve ARS-7 taş ocaklarından alınan örneklerin Saf Kalker olduğu belirlenmiştir.

\section{KAYNAKLAR}

1. Durmuş, C., 2007. Mersin Bölgesi Kıyı Koruma Yapilarının İncelenmesi. Mersin Üniversitesi, İnşaat Mühendisliği Anabilim Dalı, Yüksek Lisans Tezi, Mersin, $90 \mathrm{~s}$.

2. Yilmaz, E., 2010. Yumurtalik Liman Yapımında Dolgu Malzemesi Olarak Kullanılan Dolomitik Kireçtaşlarının FizikoMekanik Özellikleri. Çukurova Üniversitesi, Maden Mühendisliği Anabilim Dalı, Yüksek Lisans Tezi, Adana, $77 \mathrm{s.}$

3. Ketin, İ., 1966. Anadolunun Tektonik Birlikleri (Tectonic Units of Anatolian Asia Minor). M.T.A. Derg., (66), 20-34.

4. Okay, A. İ., 1989. Tectonic Units and Sutures in the Pondides, Northern Turkey. Tectonic Eevolution of the Tethyan Region: ed. A.M.C. Şengör, Nato Advanced Science İnstitute (ASI) Series (Publ.), pp. 109-116.

5. Okay, A. İ. Görür, N., 1994. Kinematic History Of The Opening Of The Black Sea And İts Effect On The Surrounding Regions. Geology, (22), 267-270.

6. Okay, A.İ., 2006. Cretaceous and Triassic SubductionAccretion, Hp/lt Metamorphism and
Continental Growth in the Central Pontides, Turkey. Geol. Soc. Am. Bull., 118: 1247-1269.

7. Bacak, G., Y1lmazer, S. A., 2011. Karadeniz Ereğli (Zonguldak) Andezitlerinin PetrografikJeokimyasal Özellikleri ve Endüstriyel Kullanılabilirliği. Karaelmas Fen ve Mühendislik Dergisi, 1 (1), 23-36.

8. TS EN 13383-1, May1s 2004. Koruma Tabakası Taşları (zırh taşı)-Bölüm 1: Özellikler, Ankara.

9. TS EN 13383-2, Aralık 2013. Koruma Tabakası Taşları (zırh taşı)-Bölüm 2: Deney Metotları, Ankara.

10.TS 706 EN 12620+A1, May1s 2009. Beton Agregaları, Ankara.

11. TS EN 1467, Haziran 2012. Doğal taşlar-Ham bloklar- Özellikler, Ankara.

12. CIRIA/CUR, 1991. Manual on the Use of Rock in Coastal and Shoreline Engineering. CIRIA Special Publication 83, Report:154, London, $607 \mathrm{p}$.

13. TS EN 1097-6, Aralık 2013. Agregaların Mekanik ve Fiziksel Özellikleri İçin DeneylerBölüm 6: Tane Yoğunluğunun ve $\mathrm{Su}$ Emme Oranının Tayini, Ankara.

14. TS 699, Mart 2009. Doğal Yap1 Taşlar1İnceleme ve Laboratuvar Deney Yöntemleri, Ankara.

15. TS EN 1097-2, Temmuz 2010. Agregaların Mekanik ve Fiziksel Özellikleri İçin DeneylerBölüm 2: Parçalanma Direncinin Tayini İçin Yöntemler, Ankara.

16. TS EN 1367-2, Nisan 2011. Agregaların Termal ve Bozunma Özellikleri İçin DeneylerBölüm 2: Magnezyum Sülfat Deneyi, Ankara.

17. TS EN 1926, Ekim 2013. Doğal Taşlar-Deney Yöntemleri-Tek Eksenli Basınç Dayanımı Tayini, Ankara.

18. TS 699, Mart 2009. Doğal Yap1 Taşlarıİnceleme ve Laboratuvar Deney Yöntemleri, Ankara.

19. Karayolları Genel Müdürlüğü, 2006. Karayolları Teknik Şartnamesi (Yol Altyapıs1, Sanat Yapıları, Köprü ve Tüneller, Üstyapı ve Çeşitli İşler). Ankara, 753 s.

20. CIRIA/CUR, CETMEF, 2007. The Rock Manual. The Use of Rock in Hydraulic Engineering. 2nd Edition. C683, CIRIA, London, 1234 p. 
21.TS 10088 EN 932-3/A1, Nisan 2006. Agregaların Genel Özellikleri için DeneylerKısım 3: Basitleştirilmiş Petrografik Tanımlama için İşlem ve Terminoloji, Ankara. 22. ASTM C-295. 1998. Standard Guide for Petrographic Examination of Aggregates for Concrete. Annual Books of Standards, 1990. 